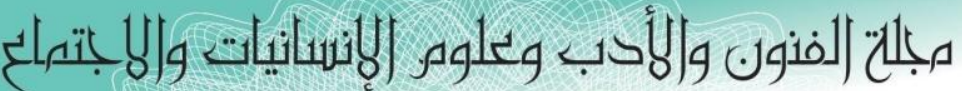

Journal of Arts, Literature, Humanities and Social Sciences

ISSN online: 2414 - 3383

أكتوبر 2019

العدد (44)

ISSN print: 2616 - 3810

Volume (44) October 2019

\title{
A Comparative Study of Iraqi and Emirati English Curriculums in Terms of Communicative Language Teaching
}

\author{
المدرس المساعد مـزند شاكر عبدالله السعدي

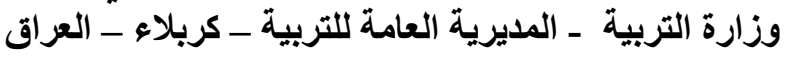

\begin{abstract}
The present study is set to make a comparison between English language curriculums for Iraq and the UAE. The sample textbooks under study are Bridge to Success, designed for the Emirati students, and English for Iraq. The paper focuses, particularly, on the four skills that should be included in a textbook set to teach English. While both books are designed to teach English to Arab students, their approach in terms of communicative language teaching is different. The Emirati book, unlike the Iraqi one, concentrates on topics which persuade maximum interactions among students. The topics presented in the book are meant to boost national pride among students and make them aware of the country's achievements in different areas. English for Iraq, however, is much less coherent in terms of its topics and also the way those topics are presented to the students. Following the analysis, the study presents certain recommendations for the designers of both curriculum, especially those who are in charge of developing the English curriculum for Iraqi students.
\end{abstract}




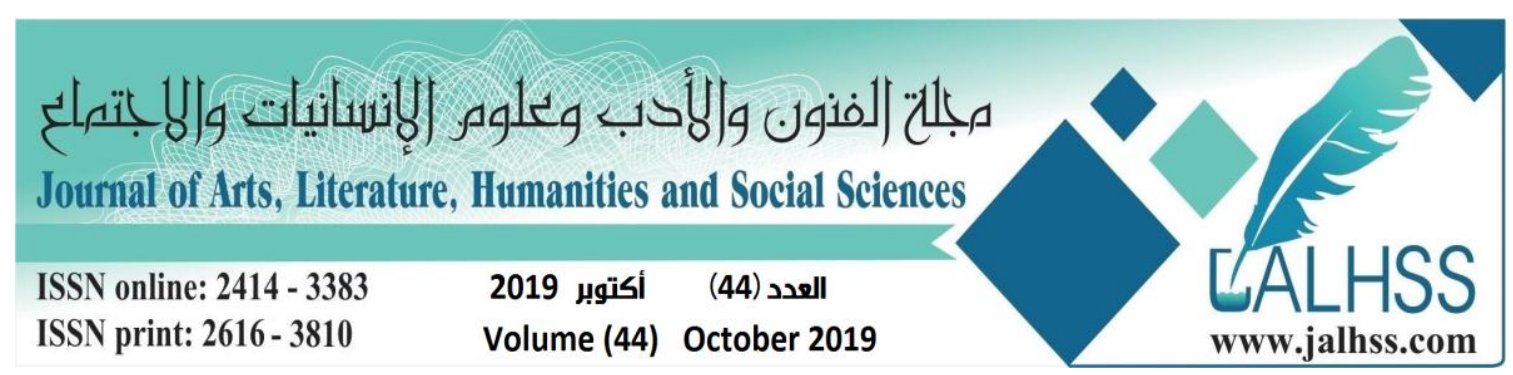

\subsection{Introduction}

It is now unanimously agreed that English has become the most widespread language in the world. English is the primary language for international communication. Besides, most written texts, and more especially scientific data, and research articles, are presented in English. As a result, teaching English as a foreign language, EFL, has turned into a crucial field of study. Teaching of English in secondary schools seeks to prepare students to keep up their education at the university level. The aim of teaching is to equip students with working knowledge of English in order to enable them to read textbooks and expand their academic and non-academic visions.

In Iraq and the UAE, English is taught as a foreign language starting from primary schools up to secondary and preparatory schools. Various schools and institutes across both countries are engaged in teaching listening, speaking, reading and writing skills. The methods teaching are essential to fulfilling the purpose(s) of learning and teaching in this context. To make teaching more interesting and meaningful, English teachers use different types of teaching methods. Traditionally, the five types of teaching methods are Grammar Translation Method (GLT), Direct Method (DM), Audio Lingual Method (ALM), Situational Language Teaching (SLT) and Communicative Language Teaching (CLT). Among these, CLT is one of most effective ones in achieving communicative competence.

The CLT approach has a resilient place in both the Iraqi and the Emirati school curriculums. This is evident in the growing popularity and concern over the publication of textbooks for teaching English in high schools. The new textbooks have been designed in such a way that they encourage students to use English for interaction on a daily basis. These books are in sharp contrast to the traditional ones that used to emphasize on a great deal of drill exercises or structured grammar-based materials. But then again, despite the availability of communication-based textbooks and the inclusion of the CLT method, most teachers in Iraq still prefer to employ the traditional grammar translation teaching method.

\subsection{The Significance of the Research}

The significance of this research project lies in drawing a comparative study between two different curricula belonging to two different countries, Iraq and the UAE. The purpose of the analogy is to demonstrate the compatibility and competency of the English language curriculum in Iraq as compared with global curriculums. The study, thus, seeks to shed more light on the low rates of success and endeavors to develop appropriate and possible solutions to raise the knowledge level of students.

\subsection{Inherent Problems in English Teaching in Iraq}

Iraqi Ministry of Education has made great achievements with regard to English teaching during the recent years. However, many shortcomings in English teaching have been found. The setbacks include: large classes, teachers' heavy workload, 


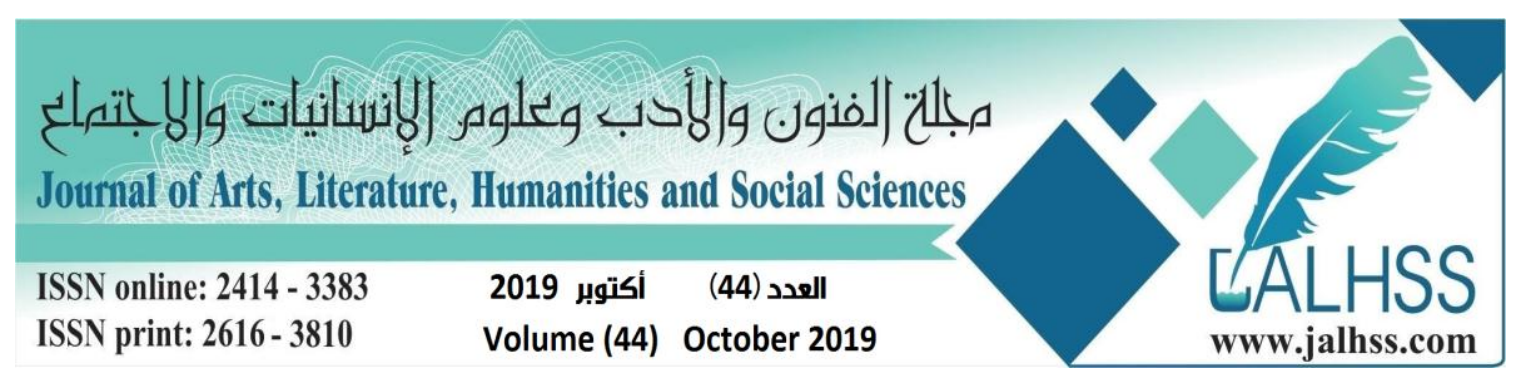

heavily-loaded program, students' poor communicative abilities, and students' low motivation.

\subsection{Communicative Approach}

The concept of communicative competence was originally developed in the early 1970s by the linguist Dell Hathaway Hymes. It is an approach to language teaching which concentrated on expanding learners' communicative skills through authentic language in meaningful frameworks. While CLT has received some negative feedbacks, it is viewed as potentially capable of developing communicative skills in English among community college students. The approach underlines the meaningful application of language for communicative purposes, rather than on the form and structure; hence the term "real-life" communication in the classroom. As CLT emphasizes on meaning rather than structure, students learn to communicate in the language "through several types of communicative activities, such as roleplays, dialogues, games and problem-solving activities" (Mustapha \& Yahaya, 2013, pp. 788-793). Previous studies conducted on this approach indicate that within CLT context, "language teaching is based on a view of language as communication, that is, language is seen as a social tool which speakers use to make meaning; speakers communicate about something to someone for some purpose, either orally or in writing" (as cited in Sreehari, 2012, p. 87).

The successful implementation of CLT in community colleges hinges highly upon the instructor's understanding of and belief in the approach which is mirrored in their actual teaching practices in the classroom. In other words, materials used by an instructor and the way he/she arranges those materials reflects his/her perception of and faith in the method. CLT has been introduced in EFL settings to help move beyond restrictions of traditional language teaching methods and improve students' abilities to use English in real contexts. As a result, the CLT approach contends that "success of learning a foreign language depends on how well learners have developed their communicative competences and how much they are able to apply this knowledge of language in real life situations" (Ansarey, 2012, pp. 61-62).

Yalden (1987) maintained that the essence of CLT "is based on the notion of the learners as communicators, naturally endowed with the ability to learn languages. It seeks to provide learners with the target language system" (p. 61) Yalden added the approach assumed that "learners will have to prepare to use the target language (orally and in written form) in many predictable and unpredictable acts of communication which arise both in classroom interaction and in real-world situations, whether concurrent with language training or subsequent to it" (p. 61). As the focus is on developing real-life language skills, "a wide variety of activities such as role plays, interviews, discussions, information gap activities, language games, language learning simulations, problem solving tasks, quizzes, and surveys are used" (Sreehari, 2012, p. 88) to ensure that students are capable of putting into practice what they have learned. 


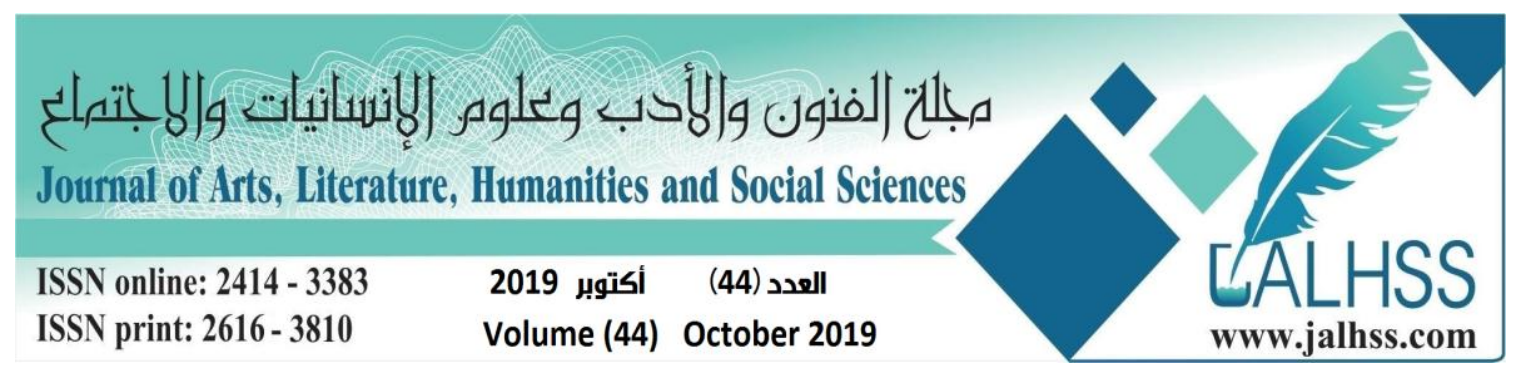

Widdowson (1990) described Communicative Approach as concentrating on "getting learners to do things with language, to express concepts and to carry out communicative acts of various kinds" (p.159). Widdowson argues that "the content of a language course is now defined not in terms of forms, words and sentence patterns, but in terms of concepts, or notions, which such forms are used to express, and the communicative functions which they are used to perform" (Widdowson p.159). Thus, CLT regards language as a system for the expression of meaning where the main function of language is to permit interaction and communication. Accordingly, the accuracy of target language is less important than the achievement of the particular communicative task.

\subsection{The Importance of Four Skills in Communicative Approach}

Language serves many purposes. Absence of language suggests downfall of communication. English is certainly the primary medium of verbal or written communication all across the globe. Based on the requirements of their learners, many institutes, schools, colleges and universities focus on one or more of the four skills, Listening, Speaking, Reading, Writing (LSRW). Language learners need these skills to "maintain relationships and better understanding which are crucial in both personal and professional life" (Tanuja, 2018, p. 527).

Listening skills could be improved by having students listen to the sounds of language, recorded speeches, dialogues and discussions. This could be focused by understanding paralinguistic attributes such as quality of voice, volume, voice modulation and pronunciation. Reading skills help students guess the meaning of unfamiliar words from the context, grasp the content and draw conclusions. This could be done through skimming scanning techniques and intensive or extensive reading. Writing provides a learner with physical evidence of his achievement so that he/she can measure their improvement. It helps boost their expansion of vocabulary, grasping structures and complements the other language skills.

Reading, writing, listening and speaking play a vital role in any language-learning endeavor. Lorena Manaj Sadiku contends that "the four skills are separate yet bound together with an inseparable bond. In fact, the integration of listening and speaking with reading and writing will make learners good listeners, speakers, readers and writers so as to be able to communicate effectively" (2015, pp. 29-30). Sadiku adds that learning these essential skills "give learners opportunities to create, contexts in which to use the language for exchanges of real information, evidence of their own ability (proof of learning) and, most important, confidence" (Sadiku, 2015, pp. 29-30). The communicative approach enables students' learning in the classroom in the form of speaking English actively and frequently. In such a context, students discuss in English and are active in reading, listening, speaking, and writing. Among the four language skills, reading and listening are called receptive and speaking, and writing are described as productive. The following objectives are usually mentioned for each of the four language skills:

\section{Reading Skill}

a) To guess the meaning of word based on the context used 


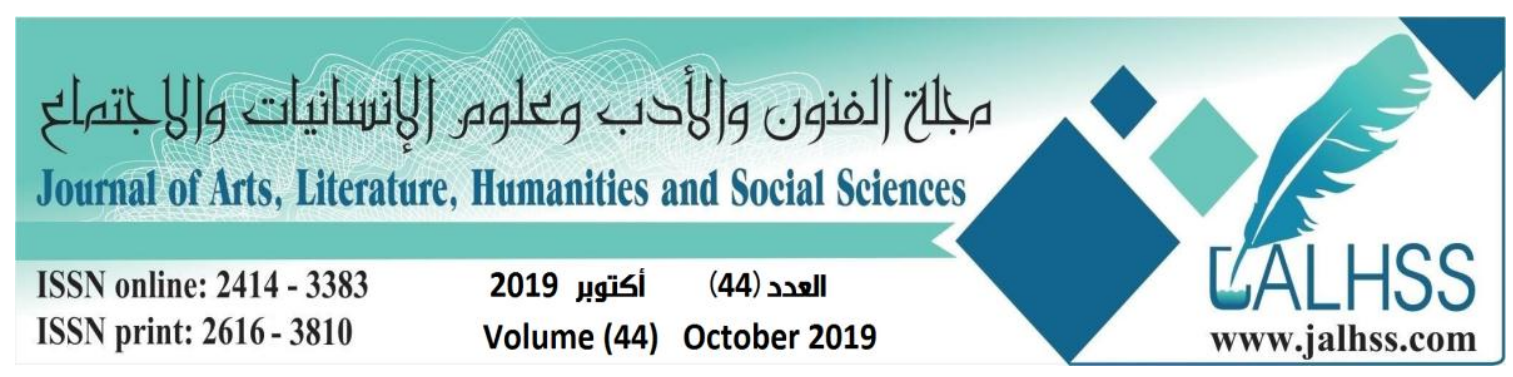

b) To determine the main idea of a reading text

c) To differentiate the fact and idea in the reading text

\section{Listening Skill}

a) To give answer of the oral questions about a topic

b) To fulfill the chart/table based on the oral information

c) To do the task based on instruction given orally

\section{Speaking Skill}

a) To give questions and answers of a topic

b) To report the result of the discussion

c) To share opinion about something important

Writing Skill

a) To make summary of reading text

b) To write the answer in order to understand the text

c) To write a formal letter and an individual letter in a good and right form.

The following sections will analyze the similarities and differences between two select textbooks for teaching English in Iraq and the UAE in terms of the four skills mentioned above and their associated activities.

\subsubsection{Reading Skill in Iraqi and Emirati Curriculums}

Reading is a basic life skill and a cornerstone for success at school. In teaching English, the main purpose of reading in English as a Foreign Language (EFL) classes is to improve comprehension. In reading classes, students are engaged in activities such as role-plays, games, problem-solving tasks, and peer and group activities. Through these activities, students are expected to actively express and share ideas. Along the way, this should help them increase their vocabulary, broaden their knowledge, be more interested to read, and also become competent users of English. Working in pairs or groups is a way "to improve the students' individual learning in the classroom. In reading, specifically, students can become reflective readers when they engage and communicate in groups" (Kustati, Yusuf, \& Maarof, 2018, pp. 649-650).

The result of the comparative analysis between Bridge to Success (the Emirati textbook) and English for Iraq reveal that the topics of reading tasks in the former are far more interesting and engaging than the latter. The Emirati book, for instance, introduces topics such as "The Mubadala Youth Forum" (p. 10) which encourages students to pursue professional career opportunities. The reading passage includes words such as "optimism", "vocational", "transition", etc. to persuade students learn new vocabularies and set high standards for the future professional path. The same mindset can be detected in the next reading passages of this book. The first reading passage of the Iraqi book, however, focuses on the story of a tourist being attacked by a shark. While it is irrelevant to the topic of the unit, which focuses on diseases, it provides no opportunities for students to share their ideas and thoughts. 


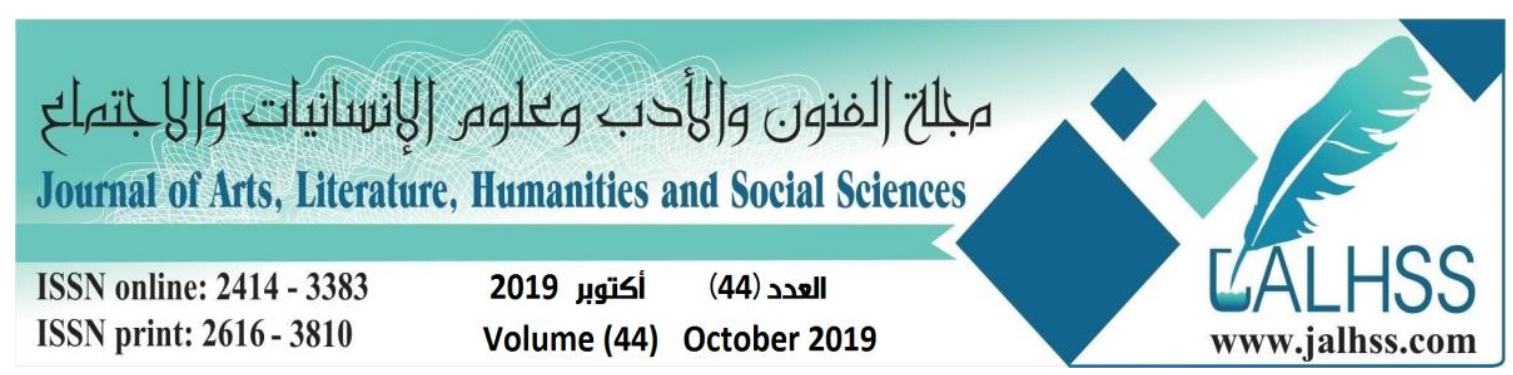

Recent studies have focused on three advantages of CLT in teaching reading. First, students are persuaded to be active learners because the techniques used in teaching reading via CLT are student-centered. In the case of Bridge to Success, reading topics frequently invite students to get involved in group discussions. Topics as diverse as workplace, Formula 1, Dubai International Airport, etc. seek to give students the most recent topics for sharing their ideas. The topics in the Iraqi book, however, are centered on teaching certain vocabularies and sentence structures rather than encouraging students to come up with ideas and opinions.

The second advantage of CLT in teaching the reading skill is enhancing students' perception of the language because it focuses on teaching functions of language. In Bridge to Success, almost all reading topics are related to the UAE. Students frequently discuss topics like Khalifa Port, local food, local heroes, etc. before they read the passages. The reading passages are set to link domestic issues with global ones in order to help students draw analogies between the two. Topics in the Iraqi book, however, are scattered and at times irrelevant. They rarely deal with Iraqi topics and at best they introduce topics related to the Arab world.

Thirdly, the implementation of CLT enables students to become highly motivated by giving them a sense of achievement when they understand and are involved in reading through the use of task-based activities. This is reflected in the rationale behind the selection of topics in the Emirati book which seeks to help students image themselves in the real-life situation presented to them.

\subsubsection{Listening Skill in Iraq and the UAE}

In recent years, with the emphasis given to communication in language teaching, listening has started to find a more prominent role in textbooks set to teach English. For most second and foreign language learners, "being able to communicate in social contexts is one of the most important reasons why they learn a language. Through listening, the learners receive input that is essential for language learning to take place" (Yıldırım \& Y1ldırım, 2016, p. 2099). Therefore, teaching listening comprehension is important as listening lessons "are a vehicle for teaching elements of grammatical structure and allow new vocabulary items to be contextualized within a body of communicative discourse" (Morley, 2001, p. 70). While all skills of language are of importance, "the sound, rhythm, intonation, and stress of the language can only be perfectly adapted through listening. To understand the nuances in a particular language, one must be able to listen. As we get to understand spoken language by listening it is easier to improve the other skills and gain confidence" (Renukadevi, 2014, p. 59).

In terms of communicative language teaching, in particular, listening establishes a firm basis for communicative competence as it provides the aural input and enables learners to interact in spoken communication and hence language learning largely depends on listening. Listening is the most significant part of communication as it is pivotal in providing a substantial and meaningful response. Especially in learning a language for communicative purpose, listening plays a vital role, as it helps the language learner to acquire pronunciation, word stress, vocabulary, and 


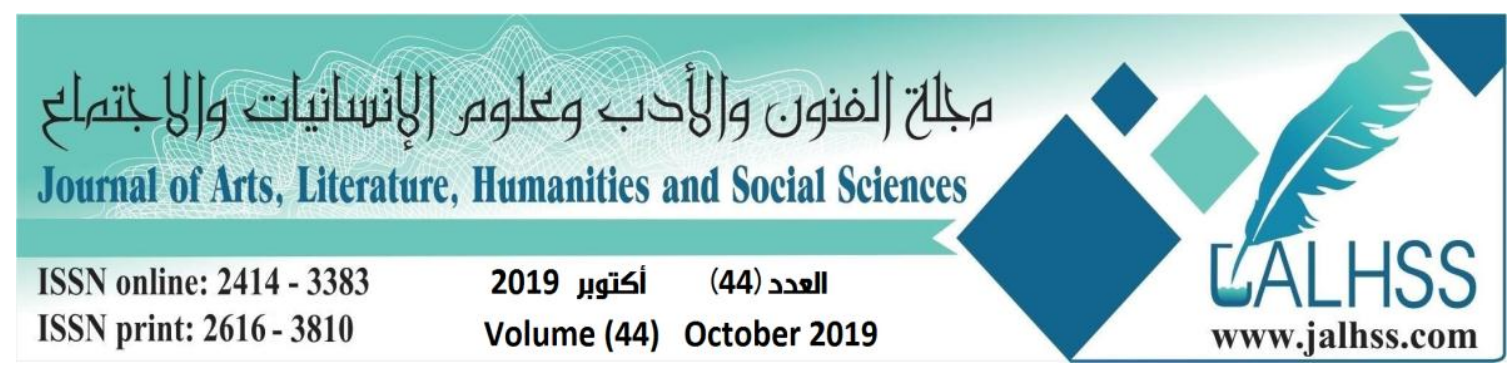

syntax and the comprehension of messages conveyed can be based solely on tone of voice, pitch and accent; and it is only possible when we listen. Without understanding input appropriately, "learning simply cannot get any improvement. In addition, without listening skill, no communication can be achieved" (Renukadevi, 2014, p.60).

The differences abound between the two books in terms of the listening activities. In Bridge to Success, there is a harmony between domestic and global topics. For instance, students have the opportunity to listen to an except about the Emirati national football teams while in another unit they listen to a part about the Chinese steel industry. The Iraqi book, however, lacks such a balance. Moreover, listening sections in English for Iraq fail to contain any sections which prepares students to the topic. They abruptly present the topic. The Emirati book, however, assigns certain tasks before students listen to the main section. This strategy is in line with the book's overall objective to create maximum interaction between students in the classroom.

\subsubsection{Speaking Skill in Iraq and the UAE}

Speaking is "speech or utterances with the purpose of having intention to be recognized by speaker and the receiver processes the statements in order to recognize their intentions" (Efrizal, 2012, p. 127). Brown \& Yule (1999) stated that "speaking is depending on the complexity of the information to be communicated; however, the speaker sometimes finds it difficult to clarify what they want to say" (p. 14). In this regard, Hughes (2006) stated that speaking is the first mode in which children acquire language, it is part of the daily involvement of most people with language activities, and it is the prime motor of language change. It also provides our main data for understanding bilingualism and language contact (p. 144).

As the main purpose of the communicative approach is facilitating communication, speaking is obviously a crucial skill within CLT framework. When you have words read, ideas written and thoughts heard, all you need is to express your speaking skill. Speaking is one important way to communicate ideas and convey messages. To enable students to communicate, we need to apply the language in real communication. Bridge to Success contains plenty of exercises with the aim of exposing students to speaking opportunities. In fact, all tasks within this book are designed to create dialogues among students before they begin doing the particular activity. Moreover, the book prepares students for giving presentations. On page 59 of the book, students are asked to follow a presentation format to prepare themselves for short presentation. Within this project, students also learn new vocabularies.

English for Iraq, however, contains much less speaking tasks. It rarely invites conversations between students. This comes from both the paucity of speaking exercises and the book's lack of attempt to choose interesting and up-to-date topics for students to discuss. The activities designed to prepare students for a particular task ask them mostly to fill in the blanks, match phrases with pictures, etc. in other 


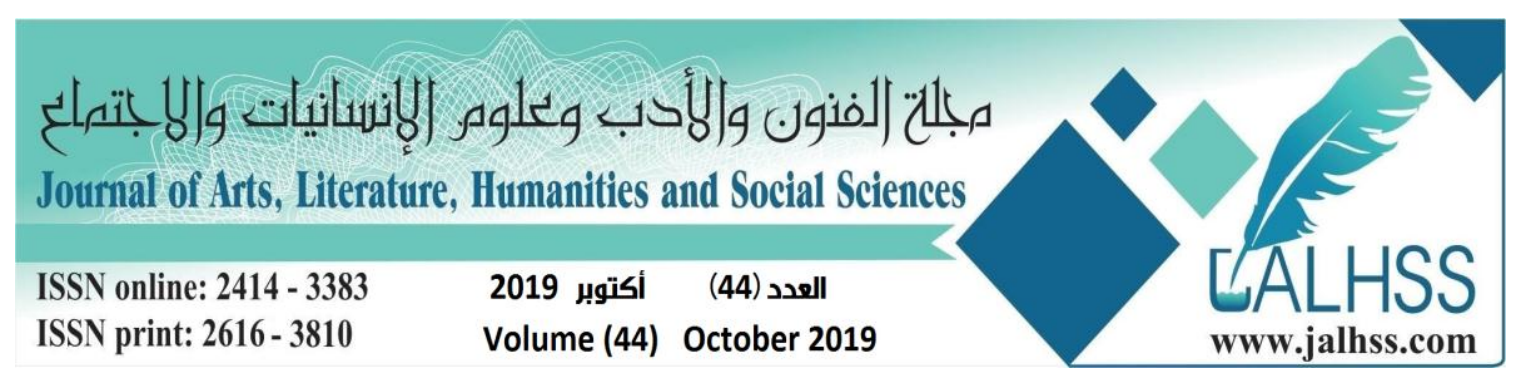

words, they seldom challenge students to express their opinions on a certain subject.

\subsubsection{How is Writing Skill Taught in Iraq and the UAE?}

The ability to write well is as important as oral proficiency for students nearly at all levels. Different studies show that the majority of students improved their writing skills by writing on a topic assigned by the teacher. Researches also indicated that a considerable number of students improved their writing through brainstorming techniques before they started to write. The writing assignment give "the opportunity to the students to be adventurous with the language, to take the risk and to go further of what is learned to talk about" (Shouman, 2002, p.1).

The writing skill is the 'hard copy' of your intellectual level or the level of your expression. The writing process is taught in schools and colleges. But, do you practice it in reality? Or Do you start to write as soon as the question is read. Pre Writing opens the doors to effective writing where you brainstorm almost anything under the topic or theme. You find a topic, narrow it, and consider the purpose, audience as well as the form of writing. You are not concerned with creating whole sentences or paragraphs at this point rather you should aim at defining an idea and getting it rolling. Then we write our first draft which is a compilation of our random thoughts. This is where our words form sentences and paragraphs. The third step is revision. Revision means "Seeing again." Here you refine the ideas in their compositions. Revising consists of three activities: rereading the rough draft, sharing the rough draft in a writing group/with anyone, and revising on basis of feedback. You can add or substitute thoughts and words. The same can be done with deleting and moving your words in the draft. Editing is the next big thing. The cleaning up process where the clutter is cleared and ideas are allowed to shine happens here. We tend to putting the piece of writing into its final form and you fine-tune your work by focusing on correct punctuation, capitalization, grammar, usage, and paragraphing. The goal here is to make the writing 'optimally readable." The last is publishing your final piece. Each step is interchangeable and can be done as many as you dare or till your writing perfects. I always tell my students to work out at least three drafts. So this is it with writing...easy? It would turn out simply simple if you make it a habit and practice like you practice your favourite song or dance. Tip: Avoid electronic English (u for you) (Sadiku, 2015, p. 31).

Writing in a foreign or second language is a courageous experience especially for students whose native language is not of the same origin as the target language. This can be a potential threat for Arab students. However, Bridge to Success has turned it to an opportunity. The use of colorful images in the writing pages is a strategy to make the writing a more appealing activity. Moreover, students are required to talk about the topic of the writing before they pick up their pencils and begin the main task. The writing part, thus, prepares students gradually to form their ideas into a coherent piece of writing. English for Iraq, on the other hand, lacks such a strategy. It follows the traditional method which makes no attempts to 


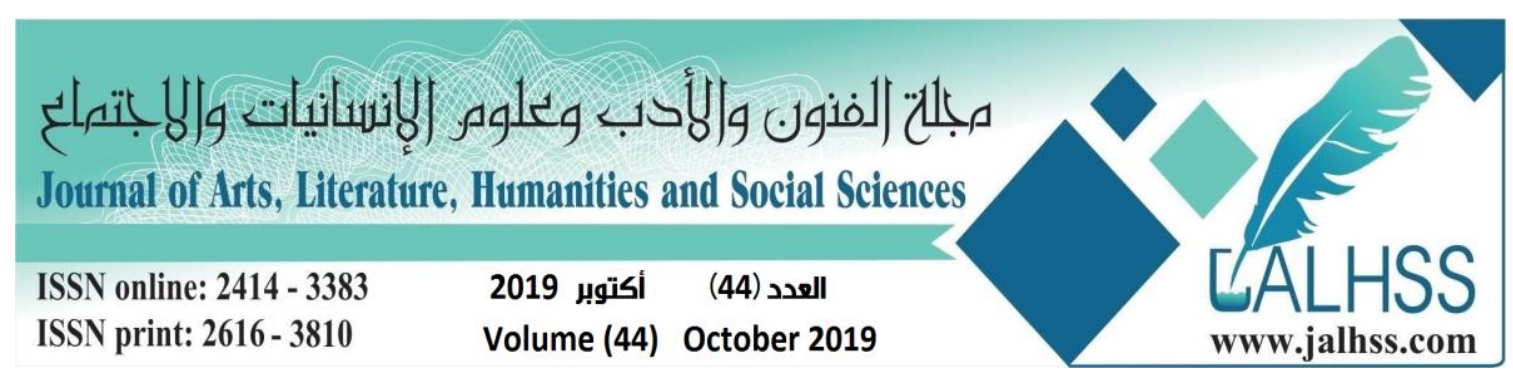

prepare students for their writing activity. In other words, the writing task is less interesting and more direct.

\subsection{Teacher's Role}

Language teaching process requires teachers' deep understanding of the aspects of language teaching and learning. When learning a second language, such as English, the teacher's existence in the classroom is even more paramount. Learning can only take place in an appropriate environment and it's commonplace that it is the teacher's job to create a favorable learning environment. Lindsay and Knight (2006) suggest that for a teacher to be affective, she needs to understand the learners' language needs and respond to them positively and design lessons which reflect the learners' needs. One of these needs is to be able to communicate well in the language which is a vital job-seeking skill. One of the characteristics that Brown (2001) advocates that learners demonstrate linguistic fluency and not just accuracy. (Mustapha \& Yahaya, 2013, pp. 788-790).

In communicative classrooms teachers will find themselves talking less and listening more, becoming active facilitators of their students' learning. The teacher sets up the exercise, but because the students' performance is the goal, the teacher must step back and observe, sometimes acting as a monitor (Banciu \& Jireghie, 2012, pp. 95-97). According to (Clifford, 1991, p.42), "The teacher has to encourage learners to write for communication. They should focus on the ideas and meanings they wish to convey rather than on mechanics of writing, such as spelling, and handwriting". Larsen-Freeman (1986) observes that "the teacher facilitates communication in the classroom. In this role, one of his major responsibilities is to establish situations likely to promote communication" ( $p$. 131).

Regarding Iraqi teachers' role in creating life-like experiences for their students, one should note that given the difficult social and political situation, teachers need to make extra efforts to encourage language learner. As Imad Harb contends "Iraq's higher education sector has the potential to play an important role in overcoming the country's widening sectarian divides and fostering long-term peace and stability" (2008, p.1). The same potentiality can be found in the English learning context in Iraq. In other words, learning English within an interactive context can be a great non-political step to help the political situation in the country.

Commenting on the nature of student-teacher interaction and the student-student interaction, Larsen-Freeman (1986, p. 133) says: "The teacher may present some part of the lesson, such as when working with linguistic accuracy. At other times, he is the facilitator of the activities, but he does not always himself interact with the students. Sometimes he is a co-communicator, but more often he establishes situations that prompt communication between and among the students. Students interact a great deal with one another. They do this in various configurations: pairs, triads, small groups, and whole group." Teachers' previous experience and 


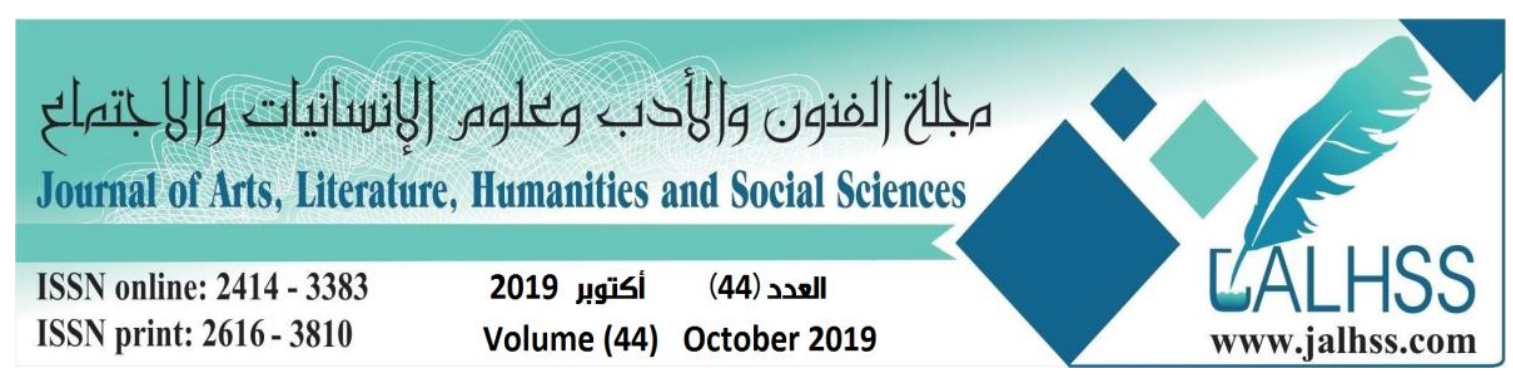

knowledge are fundamental in determining their performances. Teachers felt insecure about their level of subject-matter knowledge and indicated that they need to know more subject matter before entering the classroom. Consequently, this is similar to the case with the CLT implementation by the English teachers. Since they have less knowledge and less support to practice the approach, and so they lack the motivation and confidence to employ it in their classroom. With sufficient background knowledge and provision, the English teachers can maintain confidence to teach (Kustati, Yusuf, \& Maarof, 2018, pp. 650-659).

There are quite a few roles for teachers in CLT which are determined by the view of CLT. There are two main rules of a teacher in CLT classrooms. The first role is to facilitate the communication process among all the students in the classroom, and between the students and the different type of activities and texts. Secondly, a teacher has to act as an independent participant within the learning teaching groups. The teacher is also expected to act as a resource, an organizer of resources, a motivator, a counselor, a guide and a researcher (Ansarey, 2012, p. 63). Teachers should set high standards for an ESL classroom. They should work to create the necessary condition for students to learn effectively and reach the desired outcome. For the teaching of English to be successful, the four skills, reading, listening, speaking and writing, should be integrated in an effective way. These skills should be addressed in a way that helps students meet the standards you set for them and develop their communicative competence gradually (Sadiku, 2015, p. 29).

Teachers have a vital role in correcting problems of writing that could hinder the process of learning English. It can be done by encouraging students to write to communicate student to student, student to teacher, or student to foreigner (Dwivedi \& Chakravarthy, 2015, p. 28). To teach reading in an EFL class, the teacher should not only have knowledge on the reading subject but also on the appropriate technique needed by the students to achieve the teaching and learning goals. When individual learning does not enhance the students to accomplish the anticipated results, teachers must make decisions and move on to a technique where teamwork may facilitate reinforcement for the weak individual learners (Yusuf, Natsir, \& Hanum, 2015, p. 101).

In the implementation of teaching and learning activities the lecturer always gives assignments to the students. To support the completion of these tasks, the lecturer gave instructions on how to do the tasks, gave examples of doing the tasks, monitor student activities during their working, asking them to discuss the results of their work, providing feedback as necessary, and providing an explanation as reinforcement for what they had done and discussed (Irmawati, 2012, p. 99). During learning process of CLT, students' are hoped to communicate orally and conquer all components of communicative competence and teacher is being motivator, assessor, facilitator, and corrector during students' discussion or speaking in front of the class. In addition, the teacher also should make their lesson interesting so the students don't fall asleep during learning English (Harmer, 1998, p. 1). 


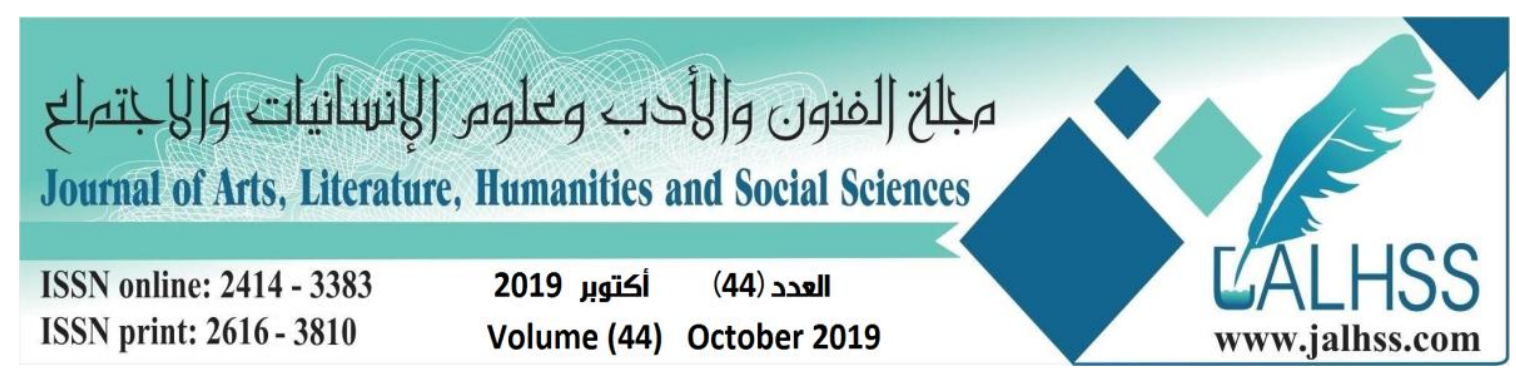

\subsection{Student's Role}

While some learners are born with a flair for languages and find language learning an enjoyable and successful experience, some others have difficulties trying to make sense of the language, hence a daunting, threatening and frustrating experience for them. (Mustapha \& Yahaya, 2013, p. 789). Students' motivation to learn comes from their desire to communicate in meaningful ways about meaningful topics. Students are more responsible managers of their own learning. Larsen-Freeman (1986, p. 131) observes that "Students are, above all, communicators. They are actively engaged in negotiating meaning - in trying to make themselves understood and in understanding others - even when their knowledge of the target language is incomplete. Also, since the teacher's role is less dominant than in a teacher-centered method, students are seen as more responsible managers of their own learning".

The communicative approach emphasizes the idea of an effective communication between the teacher and the students and focuses on language as a medium of communication. It recognizes that all communication has a social purpose learners have something to say or find out. Classroom activities maximize opportunities for learners to use target language in a communicative way for meaningful activities (Banciu \& Jireghie, 2012, pp. 95-97). Students' ability to learn the target language is determined by their competency in communication and language use in real life situations. Therefore, students learning English should be able to communicate and interact using this language (Kustati, Yusuf, \& Maarof, 2018, p. 650).

As the emphasis in communicative language teaching is on the process of communication rather than mastery of language forms, there are different roles learners can assume in the classroom: "The main role of learners is negotiating. They negotiate among themselves, the learning process and the objective learning. Learners should contribute as much as they gain, and thereby learn in an independent way. They interact within the groups and within the classroom" (Ansarey, 2012, pp. 63-64). The role of students is gaining importance. They are now parties whose role is undeniable in the process of teaching and learning. The role is reflected in the activities they carry out individually, in pairs, or in the form of group works. Although some studies have reported that working groups as one of the main features of communicative approach sometimes "lose its essential meaning" (Irmawati, 2012, p. 99) due to students' lack of motivation to participate in class activities, in most cases more interactions between learners guarantees facilitation of the learning process and high quality of the outcome.

\subsection{Findings and Conclusion}

The study examined the similarities and differences between two textbooks in Iraq and the UAE which seek to teach English to Arab students. Both books endeavor to make a balance between domestic and global issues in terms of the unit topics. However, the Emirati Bridge to Success is much more focused on celebrating 


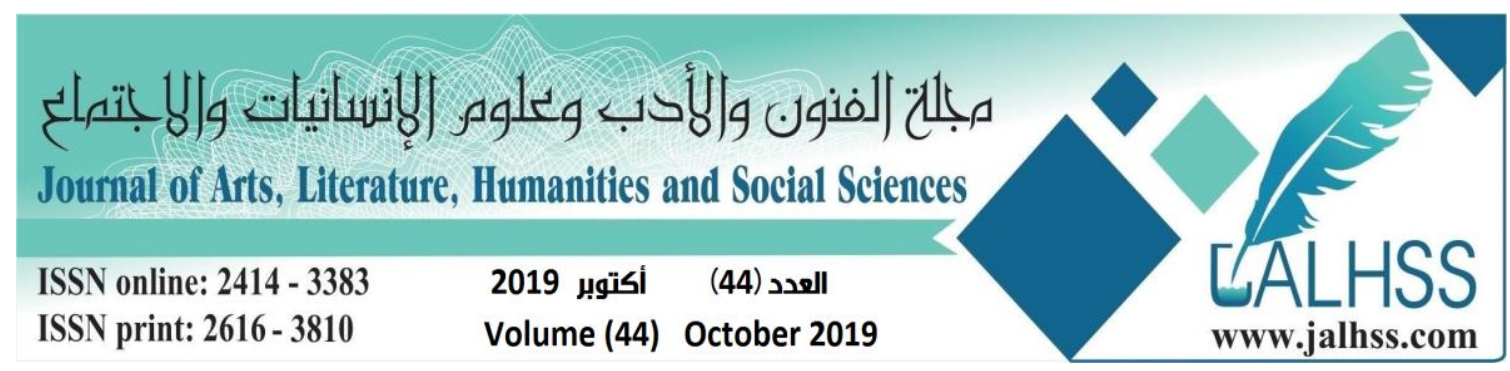

national achievements and more concerned about national pride. It seeks to present issues which are attractive to the target readers both visually and thematically. Moreover, the book is an integrated entity with a clear plan to direct students toward their learning objectives.

English for Iraq, on the other hand, is much less coherent than the Emirati book both in terms of its topics and the way they are categorized. At times, the book seeks to focus on domestic issues but the references are scattered and, sometimes, irrelevant. The book highlights domestic problems rather than achievement at home. Therefore, based on the research findings, here are some useful recommendations:

1. Massive CLT training programme needs to be provided for Iraqi English teachers;

2. Working load of both Emirati and Iraqi English teacher should be reduced;

3. Teachers must be well prepared before walking into classroom;

4. Exam system should be much more communicative in Iraq;

5. The learning environment must match the requirements of CLT;

6. Both governments must be more supportive to hinder potential obstacles;

7. Motivations among Iraqi students should be created;

8. Special care for boosting speaking and listening skills must be taken.

\section{References}

1. Al-Khatib, H. (2017). Revisiting the Communicative Approach: The Tripod Construct. Arab World English Journal (AWEJ), 8(1), 3- 15. doi:https://dx.doi.org/10.24093/awej/vol8no1.1

2. Ansarey, D. (2012). Communicative Language Teaching in EFL Contexts: Teachers Attitude and Perception in Bangladesh. ASA University Review, 6(1), 61-78.

3. Banciu, V., \& Jireghie, A. (2012). Communicative Language Teaching. The Public Administration and Social Policies Review, 1(8), 94-98.

4. Brown, G., \& Yule, G. (1999). Teaching the spoken Language. Cambridge University Press.

5. Clifford, M. (1991). Developing writing skills in basic ESL for adults. . In English Teaching Forum, 29(2), 41-42.

6. Dwivedi, R. S., \& Chakravarthy, R. V. (2015). Problems encountered by rural students in writing English-role of English teacher-some Solutions. International Journal on Studies in English Language and Literature, 3(7), 27-38.

7. Efrizal, D. (2012). Improving students' speaking through communicative language teaching method at Mts Ja-alhaq, Sentot Ali Basa islamic boarding school of Bengkulu, Indonesia. International Journal of Humanities and Social Science, 2(20), 127-134.

8. Field, J. (2008). Listening in the language classroom. United Kingdom: Cambridge University Press.

9. Harmer, J. (1998). How to teach English: an introduction to the practice of English language teaching. New York: Longman. 


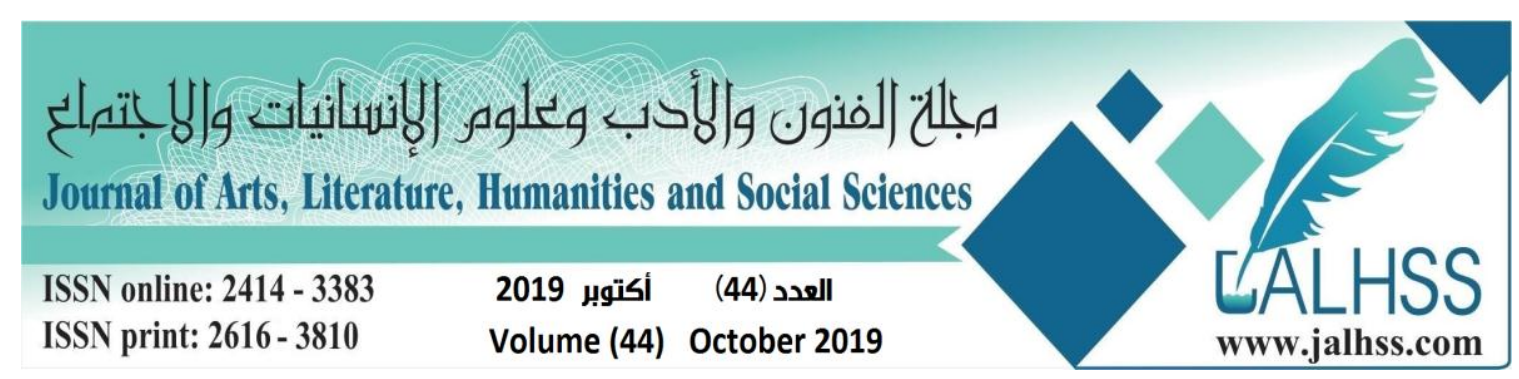

10. Hughes, R. (2006). Spoken English, TESOL, and applied Linguistics: Challenges for Theory and Practice. Great Britain: CPI Antony Rowe.

11. Irmawati, N. D. (2012). Communicative Approach: An Alternative Method Used in Improving Students' Academic Reading Achievement. English Language Teaching, 5(7), 90-101.

12. Johnston, O., \& de Messieres, C. (2013). English for Iraq. Reading: Garnet Publishing Ltd.

13. Kustati, M., Yusuf, Y. Q., \& Maarof, N. (2018). English Teachers' Voices on Communicative Language Teaching for Reading in Indonesian Rural Classrooms. Problems of Education in the 21st Century, 76(5), 649-662.

14. Larsen-Freeman, D. (1986). Techniques and Principles in Language Teaching. Oxford : Oxford University Press.

15. Ma, T. (2009). On Communicative Language Teaching. Asian Social Science, 5(4), 40-45.

16. Morley, J. (2001). Aural comprehension instruction: Principles and practices. In M. C. Murcia, Teaching English as a Second or Foreign Language (pp. 69-85). Boston: Heinle \& Heinle.

17. Mustapha, S. M., \& Yahaya, R. A. (2013). Communicative Language Teaching (CLT) in Malaysian context:its' implementation in selected community colleges. Procedia Social and Behavioral Sciences, 90, 788 - 794. doi:0.1016/j.sbspro.2013.07.153

18. Pugliese, T., Curtis, S., Malki, N., \& Laird, A. (2016). Bridge to Success. United Arab Emirates: Ministry of Education.

19. Renukadevi, D. (2014). The role of listening in language acquisition; the challenges $\&$ strategies in teaching listening. (1, Trans.) 4(1), 59-63.

20. Sadiku, L. M. (2015). The importance of four skills reading, speaking, writing, listening in a lesson hour. European Journal of Language and Literature, 1(1), 29-31.

21. Shouman, A. (2002). Teaching Writing to ESL Students. The Process Approach.

22. Sreehari, P. (2012). Communicative Language Teaching: Possibilities and Problems. English Language Teaching, 5(12), 87-93. doi:http://dx.doi.org/10.5539/elt.v5n12p87

23. Tanuja, C. (2018). Developing Writing Skills in Rural Educational Institutions:. International Journal of English Language, Literature in Humanities, 6(3), 526-536.

24. Widdowson, H. G. (1990). Aspects of Language Teaching. Oxford: Oxford University Press.

25. Yalden, J. (1987). Principles of Course Design for Language Teaching. NJ: Prentice Hall.

26. Yıldırım, S., \& Y1ldırım, Ö. (2016). The importance of listening in language learning and listening comprehension problems experienced by language learners: A literature review. Abant İzzet Baysal Üniversitesi Eğitim Fakültesi Dergisi, 16(4), 2094-2110.

27. Yusuf, Y. Q., Natsir, Y., \& Hanum, L. (2015). A Teacher's Experience in Teaching with Student Teams-Achievement Division (STAD) Technique. International Journal of Instruction, 8(2), 99-112. doi:DOI: 10.12973/iji.2015.828a 